\title{
Determination of the Toxicity of Different Discharge Waters using Acute Toxicity Tests Approved for National Pollutant Discharge Permit in Turkey
}

\author{
V. Zulal Sonmez ${ }^{1,2}$, Nuket Sivri ${ }^{1 *}$ and A. Handan Dokmeci ${ }^{3}$ \\ ${ }^{1}$ Department of Environmental Engineering, Istanbul University, Istanbul 34320, Turkey. \\ ${ }^{2}$ Department of Environmental Engineering, Duzce University, Duzce 81620, Turkey. \\ ${ }^{3}$ Department of Emergency and Disaster Management, Namik Kemal University, Tekirdag 59030, Turkey.
}

http://dx.doi.org/10.13005/bbra/2076

(Received: 02 February 2016; accepted: 04 April 2016)

\begin{abstract}
Nowadays, three methods which target the evaluation of the characteristics of ecotoxicology tests according to aquatic trophic level are well-known, approved methods. In Turkey, the toxicity dilution factor (TDF) method, approved by Turkish Water Pollution and Control Regulation, and Lebistes reticulatus the actual method name that utilizes this animal which is a high level consumer, are used in the assessment of acute toxicity levels of waste waters with different compositions. However; it is not preferred by researchers except statutory obligations due to its disadvantages in implementation. The other method Daphnia magna, which belongs to secondary trophic group, is also widely used. Vibrio fischeri which is based on bioluminescent bacteria is mostly preferred due to ability of giving fast and precise results in acute toxicity assessment tests. In this study, specific to Turkey, it is aimed to compare issues such as experimental process, time, cost, efficiency, repeatability, etc. of tests that take place in the related legislation and standards. In light of all this information, it is determined the insufficient parts about legal regulations related to toxicity in Turkey. It can be suggested that bioluminescence bacteria ( $V$. fischeri), defined all around the world recently with its precision, optimal cost, repeatability features be used in Legal Regulations of Turkey. It is aimed to contribute to scientific literature, this study being the first on suggesting an innovative approach about acute toxicity test in Turkey.
\end{abstract}

Key words: Lebistes reticulatus; Daphnia magna; Vibrio fischeri; acute toxicity; Turkish Water Pollution and Control Regulation.

Day by day, the more complex contaminants are, the bigger their effects on aquatic ecosystems become. Direct discharge of wastewater to receiving environment causes primary environmental effects such as forming toxic-carcinogenic aromatic amines under uncontrolled anaerobic conditions. It is insufficient to put forward this potential impact on living organisms in aquatic ecosystems by means of

\footnotetext{
* To whom all correspondence should be addressed. Tel.: +902124737070/17651; Fax:+902124737180; E-mail: nuket@istanbul.edu.tr
}

physical/chemical analysis ${ }^{1}$. The reason of this is that effluents having complex and toxic effects of usually unspecific contaminants and the potential synergistic or antagonistic effects among them can only be determined through toxicity tests ${ }^{2}$. Therefore, biological indicators have started to be used over time in order to determine the toxicity.

The application (implementation) on this subject, specific to Turkey, was first carried out by pengül and Müezzinoðlu ${ }^{3}$. Pengül and Müezzinoðlu ${ }^{3}$ applied toxicity test to fish at effluents of dyeing and paper industry, but could not observe any fish mortality for the dilution rates 
they applied ${ }^{2}$. Studies on ecotoxicological evaluation of industrial effluents ${ }^{4}$ with simple and low cost toxicity test usage have accelerated over time. In recent years, the necessity of toxicity evaluation in industrial effluent discharge in Turkey has been mentioned by Sponza ${ }^{5,6}$, giving examples from different sectors such as paper, leather, petroleum chemicals, textile and metal industries. In these studies, acute toxicity was determined through bioassays at four trophic levels of bacteria (floc and coliform), algae (Chlorella sp.), protozoa (Vorticella sp.), and fish (Lepistes sp.). In other studies, it has been carried out acute toxicity of potassium permanganate ${ }^{7}$ to fish bioassay, leather industry originated effluent to sea urchin (P. lividus and S. granularis), algae (S. capricornutum $)^{8}$, and
Table 1. Industries and sectors obliged to perform a fish bioassay (TDF) according to Water Pollution Control Regulation

\begin{tabular}{ll} 
TWPCR Table no & Industry \\
\hline 5 & Food \\
7 & Mining \\
10 & Textile \\
11 & Petroleum \\
12 & Leather \\
13 & Paper \\
14 & Chemistry \\
15 & Metal \\
18 & Vehicle Factories and Garages \\
19 & Mixed Industrial Effluents \\
20 & Other Industrial Effluents \\
\hline
\end{tabular}

Table 2. Toxicity Test Standards approved by Turkish Standards Institute (TSI) ${ }^{13}$

\begin{tabular}{|c|c|c|}
\hline Date & TS No & Standard name \\
\hline 4.4.1988 & TS 5676 & Water Pollution Control-Toxicity Tests \\
\hline 5.4.1990 & TS 8264 & $\begin{array}{l}\text { Industrial Effluents and Wastewaters-Acute Toxicity Tests-Bioassay } \\
\text { Methods }\end{array}$ \\
\hline 14.4.1997 & TS EN ISO 10712 & $\begin{array}{l}\text { Water quality-Pseudomonas putida growth inhibition test (Pseudomonas } \\
\text { cell multiplication inhibition test) }\end{array}$ \\
\hline 18.9.1997 & TS 11981 ISO/DIS 14669 & $\begin{array}{l}\text { Water quality-Cruslaces bioassays- Determination of acute lethal toxicity } \\
\text { to marine copepods (Copepode, Crustacea) }\end{array}$ \\
\hline 30.12.1997 & TS ISO 10229 & $\begin{array}{l}\text { Water quality-Determination of the prolanged toxicity of substances to } \\
\text { freshwater froh method for evaluating the effects of substances on the } \\
\text { growth rate of the rainbow trout }\end{array}$ \\
\hline 12.4 .2000 & TS 6020 EN ISO 7346 & $\begin{array}{l}\text { Water quality- Determination of the acute lethal toxicity of substances } \\
\text { to a freshwater fish [Brachydonio Rerio Hamilton-Buchanan (Teleostei, } \\
\text { Cyprinidae)] }\end{array}$ \\
\hline 17.3.2005 & TS ISO 10706 & $\begin{array}{l}\text { Water Quality- Determination of Long Term Toxicity of Substances to } \\
\text { Daphnia magna straus (Cladocera, Crustacea) }\end{array}$ \\
\hline 12.10 .2006 & TS EN ISO 10253 & $\begin{array}{l}\text { Water quality - Marine algal growth inhibition test with Skeletonema } \\
\text { costatum and Phaeodactylum tricornutum }\end{array}$ \\
\hline 12.10.2006 & TS EN ISO 9509 & $\begin{array}{l}\text { Water quality - Toxicity test for assessing the inhibition of nitrification } \\
\text { of activated sludge microorganisms }\end{array}$ \\
\hline 27.3.2007 & TS EN ISO 16712 & $\begin{array}{l}\text { Water quality - Determination of acute toxicity of marine or estuarine } \\
\text { sediment to amphipods }\end{array}$ \\
\hline 27.3.2007 & TS EN ISO 20079 & $\begin{array}{l}\text { Water quality - Determination of the toxic effect of water constituents } \\
\text { and waste water on duckweed (Lemna minor) - Duckweed growth } \\
\text { inhibition test }\end{array}$ \\
\hline 19.1.2010 & TS EN ISO 15088 & $\begin{array}{l}\text { Water quality - Determination of the acute toxicity of waste water to } \\
\text { zebrafish eggs (Danio rerio) }\end{array}$ \\
\hline 19.1.2010 & TS EN ISO 11348 & $\begin{array}{l}\text { Water quality - Determination of the inhibitory effect of water samples } \\
\text { on the light emission of Vibrio fischeri (Luminescent bacteria test) }\end{array}$ \\
\hline 10.4 .2013 & TS EN ISO 6341 & $\begin{array}{l}\text { Water quality - Determination of the inhibition of the mobility of } \\
\text { Daphnia magna straus (Cladocera, Crustacea) - Acute toxicity test }\end{array}$ \\
\hline 12.6.2013 & TS EN ISO 10710 & $\begin{array}{l}\text { Water quality - Growth inhibition test with the marine and brackish } \\
\text { water macroalga Ceramium tenuicorne }\end{array}$ \\
\hline
\end{tabular}


Table 3. Advantages and disadvantages of acute toxicity organisms which are mostly used in Turkey (adapted from Karci [20])

\begin{tabular}{|c|c|c|}
\hline Test organism & Advantage & Disadvantage \\
\hline \multirow[t]{3}{*}{ Microorganisms } & $\begin{array}{l}\text { Representing organisms at higher } \\
\text { trophic levels } \\
\text { More precision compared to } \\
\text { invertebrates and fish } \\
\text { Repeatability of tests } \\
\text { Resulting in } 30 \text { minutes rather } \\
\text { than days/hours } \\
\text { More optimal cost } \\
\text { More ethical because it does not harm } \\
\text { higher structured organisms } \\
\text { Storage of reagent/ auxiliary chemicals } \\
\text { for about } 1 \text { year } \\
\text { Being appropriate for all air, surface and } \\
\text { underground water, effluent, sediment, } \\
\text { and chemical samples } \\
\text { No need for ventilation even in samples } \\
\text { of effluents/underground waters with low } \\
\text { level dissolved oxygen } \\
\text { Working on small sample volumes in } \\
\text { millilitres } \\
\text { No need to prepare cultures due to freeze } \\
\text { dried reagents(optional) } \\
\text { No possibility of being exposed to different } \\
\text { toxicants throughout their lifecycle and low } \\
\text { possibility of adaptation } \\
\text { The real reason of death being highly } \\
\text { toxicant based } \\
\text { No need for specialisation }\end{array}$ & $\begin{array}{l}\text { Possibility of the sample losing its own } \\
\text { feature due to special sample } \\
\text { preparation (solvent, salinity, pH } \\
\text { adjustment, etc.) }\end{array}$ \\
\hline & $\begin{array}{l}\text { Being types having economical or } \\
\text { ecological importance }\end{array}$ & $\begin{array}{l}\text { Lack of information in methods of } \\
\text { cultures many types }\end{array}$ \\
\hline & Being small-sized, and having a short & $\begin{array}{l}\text { Possibility in being exposed to the } \\
\text { former }\end{array}$ \\
\hline Invertebrates & $\begin{array}{l}\text { Lifecycle } \\
\text { Getting genetically uniform cultures, } \\
\text { standardised stock organism }\end{array}$ & $\begin{array}{l}\text { toxicant during lifetime } \\
\text { Difficulty in knowing real reason of } \\
\text { death }\end{array}$ \\
\hline & $\begin{array}{l}\text { Understandable toxicant intake, } \\
\text { behaviour, and reactions }\end{array}$ & $\begin{array}{l}\text { Different reaction of different types due } \\
\text { to physiological differences }\end{array}$ \\
\hline & $\begin{array}{l}\text { Appropriate for monitoring pollution in } \\
\text { aquatic systems }\end{array}$ & $\begin{array}{l}\text { Long lasting test } \\
\text { Standardisation problems }\end{array}$ \\
\hline & Good precision, realtime analysis & High amount of sample volume \\
\hline Fishes & & $\begin{array}{l}\text { Difficulty in knowing real reason of } \\
\text { death } \\
\text { Being affected by environmental } \\
\text { parameters } \\
\text { Possibility in being exposed to the } \\
\text { former toxicant during lifetime, giving } \\
\text { different reactions }\end{array}$ \\
\hline
\end{tabular}


textile industry originated effluent to Daphnia magna $^{9}$.

In this study, it is aimed to make a comparison on issues such as experimental process, time, cost, efficiency of test organisms taking place in the related regulations and standards specific to Turkey. Moreover, taking all industrial sectors into consideration, it is aimed to contribute to scientific literature with this study as the first to suggest innovative approaches to the related legislative regulations in Turkey.

\section{Acute toxicity approach in turkey}

Acute toxicity test was entered in force in Turkey with 'Water Pollution Control Regulation (WPCR) No. 25687 dated 04.09.1988 ${ }^{10}$. The term toxicity is based on a fish bioassay in determining acute toxicity in the related regulation. According to this regulation, toxicity is defined as 'to have the feature of leading to threaten human health, health of various indicator organisms, and the ecosystem balance; acute or chronic diseases, teratogenic, genetic deformity and measurement (indication) by being within water in an amount more than a definite concentration' and TDF (toxicity dilution factor) is defined as 'measurement used to determine the toxicity level of effluents' [11]. It is used to determine the effect of toxicity on fish that are indicator organisms of effluent. The survival of fish in the end of $48 \mathrm{~h}, 72 \mathrm{~h}$, and $96 \mathrm{~h}$ in different dilutions of effluent is determined through this experiment. It is a standard experiment providing the relationship of toxicity with dilution rates.

Fish bioassay is required from the industrial sector given in Table 1. Wastewater coming from industries such as textile, leather, and chemicals is known to be potentially carcinogenic, and contain hazardous and toxic compounds. Effluents of these industries, having high chemical oxygen demand (COD) and suspended solids (SS), use excessive water and chemical substances at the same time. Besides the excessive water use, in mining, metal and petroleum industries have also heavy metal content having toxic effects. In the treatment of all these effluents, advanced oxidation process is needed except conventional treatment. If proper and sufficient treatment is not done, different chemical and heavy metal containing, and high volume effluents with high loads of organic substances will come out. These types of wastewaters may cause to the inhibition of performance on urban sewerage systems or secondary treatment units ${ }^{12}$. When taken into consideration that treatment will end in receiving environment, its effect on aquatic organisms is inevitable.

Although not included in Water Pollution Control Regulation, there are some toxicity test standards approved by Turkish Standards Institute (TSI) (Table 2). Among these, especially the freshwater type of Daphnia, Daphnia magna, is used as a test organism in water quality control, and studies as well as on the determination of the toxicity of wastewater and/or chemicals.

Acute toxicity tests carried out with Daphnia magna have taken place in academic studies very often ${ }^{14-16}$. This organism is used due to its rapid growth rate, high spawning potential, short life cycle and having indicator features ${ }^{17}$. Studies are carried out on different test organisms about effluent toxicity within the scope of SCI. In studies carried out between 2003 and 2015 in Turkey, acute toxicity tests using Daphnia magna attract most attention. Another one acute toxicity tests known as Resazurin method ${ }^{18,19}$ carried out using bacteria. Although not preferred by scientists, fish bioassay is also one of the most widely used tests due to its presence in official regulations.

\section{DISCUSSION}

Toxicity on which there are many studies carried out worldwide, by analysing the legislative regulations especially in Turkey it can be seen that it is not at a sufficient level. While the last revision of Water Pollution and Control Regulation was done on 24.04.2011, it has not been revised since the addition of toxicity tests into the regulation. In the Turkish Regulation, fish bioassay and toxicity dilution factor is the only toxicity monitoring parameter for the permission of effluent discharge. The insufficiency determined in the related regulation can be stated as gaps in legislative regulations, way of practice, and insufficiency of test organisms used in acute toxicity tests.

Many of the acute toxicity tests used by Turkish Standards Institute are in English language. Furthermore many standards have not been translated into Turkish, however, they should be 
translated into the first language in order to enable those who are interested in this subject to have a more active role in these studies.

In Turkey, where industrialisation is increasing constantly, discharge of effluent of both the difficult ones to treat and the ones where more than one type of effluent is mixed, is done after conventional treatment. This causes the toxicant to increase its pressure on the recipient environment, and the xenobiotics to enter the environment easily. According to Water Pollution Control Regulation, with the statement "If found necessary by the related authority, Fish Bioassay is checked in investigations" the only parameter that reveals the effect of toxicants on ecosystems may be eliminated.

Environment issues have gained importance in Turkey together with the improvements worldwide. Especially in the frame of the EU membership negotiations, Turkey should develop and update its legislative regulations on water resources. Having approximately 100 laws and regulations, and many organizations and institutions in the management of water resources being effective in the issue in our country causes some complications. When our legislative regulations are evaluated in terms of acute toxicity, primarily there should be different organisms and laboratory studies including protocol use for the evaluation of toxicity. The aim of these studies should be obtaining sufficient information on acute toxicity with bioluminescent bacteria that is an appropriate bioassay, having the advantage of superseding fish bioassays due to its being more ethical for animal welfare, being easy, highly precise, and relatively cheap. As an untouched issue, acute toxicity tests should be brought into question by organisations and institutions cooperating with universities. Thus, it is foreseen that following the developed countries, improvements in acute toxicity determination may occur.

\section{CONCLUSIONS}

The results of toxicity test indicate the potential hazard to the aquatic ecosystem. It is necessary to make the risk evaluation of toxicants based on national/international regulations in order to be able to evaluate the results of the tests. Thus, it is possible to keep the chemicals that may occur in the environment within the frame of Acceptable Risk Level (ARL). Even if sectors determined in the related regulation do not exceed the limits of effluent discharge, they may cause toxicity. However, effluent investigated for its Toxicity Dilution Factor (TDF) does not indicate its toxicity completely. The most important insufficiency of Toxicity Dilution Factor is that it does not measure the reaction of organisms while indicating toxicity. As Aydýn and Kara ${ }^{2}$ mentioned in their studies, although 30 times diluted effluent does not cause fish death, it is impossible to predict the real effect of it or how it reacts when diluted 10 times. Therefore, $\mathrm{LC}_{50}$ is preferred to TDF in tests of fish bioassays carried out in Turkey by researchers.

It has been tried to determine hazards that may occur in aquatic ecosystem by using more than one organism in many studies. Due to these organisms at different trophic levels showing different sensitivity, a number of series of test application is needed. Nevertheless, feasibility of bioassays carried out with more than one organism is low due to its time and cost factors. The reason of failure of fish bioassays is this infeasibility. What really matters is finding the most precise, the most appropriate, and the most accurate method. In the selection of the suitable test organism, with its representing the ecosystem, easy organism supply/preservation feature, wide range of sensitivity, high adaptation capacity, and being less affected by environmental parameters, the type of test organism becomes more advantageous. Due to this reason, test organisms categorized according to their trophic levels given in Table 3 should be investigated with their advantages and disadvantages. It can be recommended to use bioluminescent bacteria ( $V$. fischeri), being recently defined worldwide with its sensitivity, optimal cost, and repeatability, in Turkish Legislative Regulations. In developed countries such as the USA, Germany, France, and Spain, this test has been approved to be the prominent acute toxicity test accepted as an official standard.

\section{ACKNOWLEDGMENTS}

This work was supported by the Research Fund of the Istanbul University (Project number: YL-55426). Authors would like to thank M. Kutay SIVRI for his critical reading and quick editing. 


\section{REFERENCES}

1. Villegas-Navarro., A, González, M. R., Lopez, E.R., Aguilar, R.D. and Marcal, W.S., Evaluation of Daphnia magna as an Indicator of Toxicity and Treatment Efficacy of Textile Wastewaters. Environment International, 1999; 25(5): 619624.doi:10.1016/S0160-4120(99)00034-3.

2. Aydýn, M.E. and Kara, G., Toxicity of Organizated Industrial Zone Wastewater. Journal of the Faculty of Engineering and Architecture of Selcuk University, 2006; 21(34), 13-20.

3. a engül, F. and Müezzinoðlu, A., Atýksularda Balýk Biyodeneyinin Uygulanmasý ve ZSF Hesabý ile Ýlgili Bir Örnek Çalýpma. MSc diss., Dokuz Eylül University. (in Turkish), 1987.

4. Aydýn, M.E., Aydin, S., Tongur, S., Kara, G., Kolb, M., Bahadir, M., Application of Simple and Low-Cost Toxicity Tests for Ecotoxicological Assessment of Industrial Wastewaters. Environmental Technology, 2015; 36(22): 1-34. doi:10.1080/09593330.2015. 1049216.

5. Sponza, D.T., Incorporation of Toxicity Tests into the Turkish Industrial Discharge Monitoring Systems. Archives of Environmental Contamination and Toxicology 2002; 43(2): 186197. doi: 10.1007/s00244-002-1150-2.

6. Sponza, D.T., Necessity of Toxicity Assessment in Turkish Industrial Discharges (Examples from Metal and Textile Industry Effluents). Environmental Monitoring and Assessment, 2002; 73(1): 41-66.

7. Aslantürk, A. and Çetinkaya, O., Acute Toxicity of Potassium Permanganate $\left(\mathrm{KMnO}_{4}\right)$ on Guppy (Poecilia reticulata, Peters, 1859). Süleyman Demirel Üniversitesi Eðirdir Su Ürünleri Fakültesi Dergisi, 2014; 10(1): 12-19. (in Turkish).

8. Oral, R., Meriç, S., Nicola, E. D., Petruzzelli, D., Rocca, C. D. and Pagano, G., Multi-Species Toxicity Evaluation of a Chromium-Based Leather Tannery Wastewater. Desalination, 2007; 211(1): 48-57.

9. Meriç, S., Selçuk, H. and Belgiorno, V., Acute Toxicity Removal in Textile Finishing Wastewater by Fenton's Oxidation, Ozone and Coagulation-Flocculation Processes. Water Research, 2005; 39(6): 1147-1153. doi:10.1016/ j.watres.2004.12.021.

10. TWPCR, Turkish Water Pollution Control Regulation, Official Gazette No. 19919, 1988; 4.

11. Bahadýr, E. B. and Meriç Pagano, S., Statistical Correlation of Toxicity Monitoring Method with
Pollution Parameters for Industrial Wastewater Discharges in Turkey. Nigde University Faculty of Engineering and Architecture Journal of Engineering Sciences, 2013; 2(2): 1-8 (Turkish).

12. Birgül, A. and Solmaz, S. K. A., Investigation of COD and Colour Removal on a Textile Industry Wastewater Using Advanced Oxidation and Chemical Treatment Processes. Ecology 2007; 15 (62): 72-80. (Turkish).

13. URL 1: Turkish Standards Institution (TSI). https://www.tse.org.tr/tr/Default.aspx (acessed on: December 2015).

14. Meriç, S., Kaptan, D. and Ölmez, T., Color and COD Removal from Wastewater Containing Reactive Black 5 Using Fenton's Oxidation Process. Chemosphere, 2004; 54(3): 435-441. doi:10.1016/j.chemosphere.2003.08.010.

15. Arslan-Alaton, I., Degradation of a Commercial Textile Biocide with Advanced Oxidation Processes and Ozone. Journal of Environmental Management, 2007; 82(2): 145-154. doi:10.1016/ j.jenvman.2005.12.021.

16. Sponza, D. T. and Kuscu, Ö. S., Relationships between Acute Toxicities of Para Nitrophenol (P-NP) and Nitrobenzene (NB) to Daphnia magna and Photobacterium phosphoreum: Physicochemical Properties and Metabolites under Anaerobic/Aerobic Sequentials. Journal of Hazardous Materials, 2011; 185(2): $1187-$ 1197. doi:10.1016/j.jhazmat.2010.10.030.

17. Sarý, E., 2011, Investigation of Acute Toxicity of Nickel to Daphnia magna (straus,1820)(Crustacea:Cladocera). MSc diss., Ankara University. (in Turkish).

18. Kargi, F., and Konya, I., COD, ParaChlorophenol and Toxicity Removal from ParaChlorophenol Containing Synthetic Wastewater in an Activated Sludge Unit. Journal of Hazardous Materials, 2006; 132(2): 226-231. doi:10.1016/j.jhazmat.2005.09.040.

19. Eker, S. and Kargi, F., Kinetic Modeling and Parameter Estimation in Biological Treatment of 2, 4-Dichlorophenol Containing Wastewater Using Rotating Perforated Tubes Biofilm Reactor. Enzyme and Microbial Technology, 2006; 38(6): 860-866. doi:10.1016/j.enzmictec. 2006.01.012.

20. Karci, A., Degradation of Chlorophenols and Alkylphenol Ethoxylates, Two Representative Textile Chemicals, in Water by Advanced Oxidation Processes: The State of The Art on Transformation Products and Toxicity. Chemosphere, 2014; 99: 1-18. doi:10.1016/ j.chemosphere.2013.10.034. 